\title{
The Application of Barcodes on Deed of Land Made by Land Deed Officials
}

\author{
Ilham Abbas and Aan Aswari \\ Universitas Muslim Indonesia, Makasar, Indonesia \\ E-mail : aanaswari@umi.ac.id
}

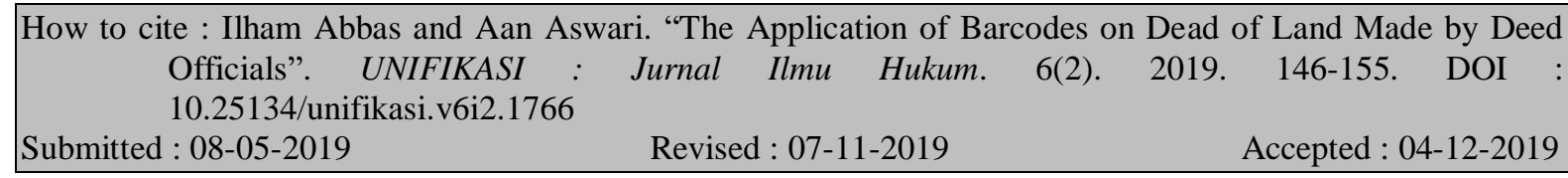

\begin{abstract}
Land officials' services related to the preparation and manufacture of deed blanks for Land Deed Officials (PPAT) has been developed by no longer using special blanks for deed and replacing it with the application of barcodes on deed of land. It aims to replace the registration number issued by land officials and to apply various technologies to a deed of land to develop various aspects in order to realize an efficient legal certainty. Besides, it also aims to provide an overview that can be used as a reference in legal problem solving where the legislation shall provide stronger legal certainty to deed of land. This study applied a legal normative and conceptual research design. The results showed that there is a form of cultural lag as an ongoing issue when new regulation is applied, namely the application of barcodes as a substitution to registration numbers. Finally, it can be concluded that the application of barcodes in the making of deeds in Land Deed Officials still encounters problems, particularly in terms of proof consequences.

Keywords: deed of land, barcode, land deed officials
\end{abstract}

\section{Penerapan Kode Baris pada Akta Tanah yang dibuat oleh Pejabat Pembuat Akta Tanah}

Peningkatan pelayanan kantor pertanahan terkait penyiapan dan pembuatan blanko akta untuk Pejabat Pembuat Akta Tanah (PPAT) telah dikembangkan dengan tidak lagi menggunakan blanko khusus untuk Akta PPAT dengan mengganti sistem pembuatan blanko oleh PPAT itu sendiri dengan penerapan kode baris pada akta tanah, bertujuan untuk mengganti nomor registrasi yang dibuat oleh kantor pertanahan dan mengaplikasikan beragam teknologi kedalam sebuah akta tanah untuk mengembangkan beragam aspek demi mewujudkan sebuah kepastian hukum dengan efisien, diantaranya dapat ditemukannya bentuk-bentuk kekuatan dan legalitas PPAT melalui perbuatan-perbuatan hukumnya, serta bertujuan untuk memberikan gambaran yang dapat dijadikan rujukan legal problem solving dimana seharusnya ketentuan peraturan perundang-undangan memberikan kepastian hukum yang semakin kuat terhadap akta tanah. Metode penelitian menggunakan legal normative research dan conceptual research sehingga secara konsisten mengurai hasil penelitian menunjukkan adanya bentuk cultural lag sebagai masalah yang berkelanjutan ketika diberlakukannya aturan baru yaitu penerapan kode baris sebagai pengganti nomor registrasi akta, khususnya dibidang pembuktian dalam upaya menggapai sebuah kepastian hukum. Akhirnya tulisan ini menyimpulkan bahwa pemanfaatan teknologi kode baris pada pembuatan akta dalam pelayanan kantor pertanahan yang diperankan oleh pejabat yang ditunjuk masih menyisakan problematika dalam penerapannya, khususnya konsekuensi dalam pembuktian.

Kata kunci: akta tanah, kode baris, ppat

\section{INTRODUCTION}

Article 33 of the 1945 Constitution of the Republic of Indonesia as a basic provision of "Under the Power of the State" states the basic economic system and economic activities are not independent matters as they are related to welfare and social justice. The effort to understand Article 33 of the 1945 Constitution of the Republic of Indonesia is inseparable from the thought of welfare and social justice for all people. Thus, the purpose of the state's power over natural resources, especially land, is an embodiment of social justice to realize prosperity for all people. This effort can be implemented through the development of various regulations as a guidence to take actions in this globalization era. 
The power of the state over the earth or land means that the State holds the power to control, regulate and manage all natural resources in the jurisdiction of the State of Indonesia. ${ }^{1}$ Article 33 Paragraph (2) and Paragraph (3) of the 1945 Constitution of the Unitary State of the Republic of Indonesia describe that the existence of rights is in line with the term "under the power of the state". Yet, it should be noted that a right is a power (macth) organized by law based on decency (moral) so that power is not merely a right as only the power justified by law which can be the basis for the right of the state to regulate. ${ }^{2}$ Registering land ${ }^{3,4}$ will involve various government agencies from the village level, sub-district level, Land Office (Kantah) of Regency/City, and Land Deed Officials (PPAT). In this case, PPAT will assist the community in any stage of land registration, namely providing various data or information that will be used as a basic reference in land registration. ${ }^{5}$ PPAT is expected to carry out its duties optimally in order to get trusted information that will be written in a deed of land as the data has a crucial role in land registration process so that the community can get legal protection over their land. Thus, it can be seen that the role of $\mathrm{PPAT}^{6}$ becomes very decisive due to its responsibility over the credibility of the data written in a deed of land. Besides, they should submit the deed of land along with other documents to Land Office within 7 (seven) working days from the date of signing. ${ }^{7}$

PPAT has an important and strategic role in land registration process because Land Office cannot issue the right over land to certain legal subject without deed issued by PPAT. Regulation of the Minister of Agrarian Affairs/Head of the National Land Agency (BPN) No. 3 of 1997 concerning Provisions for the Implementation of Government Regulation No. 24 of 1997 concerning Land Registration states that all deeds issued by PPAT are made by utilizing special blank of deed for PPAT that has been printed by BPN or other agencies. In other words, PPAT can only issue a deed by utilizing special blank of deed printed by BPN. The restriction on the making of a deed against PPAT will reduce the nature of PPAT as a public official so that it is considered important to give PPAT the same authority as a Notary in issuing an independent deed so that it is not just filling in the blank of deed. Accordingly, a Regulation of the Head of BPN RI No. 8 of 2012 concerning Amendment to Regulation of the Minister of Agrarian Affairs/Head of the National Land Agency (BPN) No. 3 of 1997 concerning Provisions for the Implementation of Government Regulation No. 24 of 1997 concerning Land Registration is issued in an effort to improve services in the field of land. Hence, since January 2, 2013, PPAT can prepare and create their own blank of deed, including Substitute PPAT, temporary PPAT, and special PPAT. In this regard, they no longer use blank of deed printed by BPN or other agencies, as stated in Article II, letters (a), (b) and (c).

Yet, the issuance of Regulation of the Head of BPN RI No. 8 of 2012 presents a new problem, namely the new model of deed no longer uses the code number that is used as a differentiator of deed and no longer has a serial number that serves to anticipate the emergence of double certificates or

\footnotetext{
${ }^{1}$ Gatra, D., Pasamai, S., Kadir, H., Buana, A. P., \& Aswari, A. (2018). Stagnancy of Land Use Arrangement Former Cultivation Rights. Substantive Justice International Journal of Law, 1(1), 1-8, 2

${ }^{2}$ Rokhim, A. (2017). Hubungan Kontraktual Antara Pemerintah Dan Kontraktor Swasta Dalam Kontrak Pertambangan Minyak Dan Gas Bumi. Rechtidee, 12(1), 27-46, 29

${ }^{3}$ Boedi Harsono, 1978, Beberapa Analisis Tentang Hukum Agraria II, Esa Studi Klub, Jakarta, 9.

4 Maria S.W. Sumardjono, dalam (Hendy Srmyendra dkk), Kekutan berlakunyaPenggunaan Blangko Akta oleh Notaris/Pejabat Pembuat Akta Tanah dalam Pengalihan Hak Atas Tanah di Kabupaten Malinau Kalimantan Utara, Jurnal Baraja Niti, volume 3 Nomor 4, 2014, ISSN,;2337-4608.2.

${ }^{5}$ Hayati, N. (2016). Peralihan Hak dalam Jual Beli Hak Atas Tanah (suatu Tinjauan terhadap Perjanjian Jual Beli dalam Konsep Hukum Barat dan Hukum Adat dalam Kerangka Hukum Tanah Nasional). Lex Jurnalica, 13(3), 284

${ }^{6}$ Novista, S. (2018). Tanggung Jawab Notaris-Ppat Dalam Mengeluarkan Covernote (Master's thesis, Universitas Islam Indonesia).16.

${ }^{7}$ Purwaningsih, E., Praptomo, S., \& Rahmi, I. G. A. K. (2015). Keharusan Penggunaan Blangko Akta Ppat Berdasarkan Perkaban Nomor 8 Tahun 2012 di Kabupaten Sukoharjo. Repertorium, 3, 96-97.
} 
deeds of land. ${ }^{8}$ Yet, this issue is anticipated by the use of barcode on each deed issued to provide legal certainty for the deed holder. Barcode and barcode scanner, ${ }^{9}$ in its use, have two additional advantages, namely: (1) Minimizing errors in data input caused by electronic system operator or cashier and (2) reducing the long queues as a barcode scanner is a smart step for inputting data. Barcode is a symbol in the form of lines representing a code or character string, or is a symbol marking objects made of bar patterns in black and white. ${ }^{10}$ The symbol can be read by a barcode scanner. ${ }^{11}$ There is another function of barcode, namely realizing efficiency in inputting data as it works automatically in inputting data. The types of one-dimensional barcodes are as follows: ${ }^{12} 1$ ). Code 128; 2). Code 39 (code 3 of 9); and 3). Interleaved 2 of 5 (ITF). Along with the development of science and technology and the use of information by community, the marking technique of objects is increasingly developed, starting from the discovery of linear barcodes, 2D barcodes, to marking techniques using infrared (IR) and radio frequencies (RFID). Some two-dimensional barcode known and utilized by the global community are: ${ }^{13}$ 1). Array Tag; 2 ). Aztec Kode and 3). Codablock

Recently, QR Code, which is a type of matrix code or two-dimensional barcode, is developed by Denso Wave in which a division of the Japanese company published this product in 1994. QR, which stands for Quick Response, aims to convey information and get responses quickly with the help of QR scanners. ${ }^{14}$ Unlike barcode which only stores information horizontally, QR Code is able to store a variety of information both horizontally and vertically so that QR Code can store more information than barcode. ${ }^{15}$ Based on the description, the problems discussed in this study are formulated into the following questions: (1) how is the power of proof of registration number before and after the enactment of Regulation of the Head of BPN RI No. 8 of 2012? and (2) how is the application of barcode as a substitution to registration number in providing legal certainty of deed made by PPAT?

\section{RESEARCH METHODS}

This legal normative and conceptual research applied a statutory and conceptual approach. The statutory approach was carried out to examine the regulations governing the registration number of deed which is believed to still have a vegenorm, while the conceptual approach was used to understand the concept of legal protection in the form of legal certainty towards the deed holder. The data were then analyzed qualitatively by describing and prescribing various findings related to the problems discussed. The result was a deductive conclusion which is the answer to the problems discussed in this study.

\section{RESULTS AND DISCUSSION}

\section{The power of proof of deed registration number before and after the enactment of} Regulation of the Head of BPN of the Republic of Indonesia No. 8 of 2012

\footnotetext{
${ }^{8}$ Silviana, A. (2012). Kajian Tentang Kesadaran Hukum Masyarakat dalam Melaksanakan Pendaftaran Tanah. Pandecta: Research Law Journal, 7(1). Hlm, 119

${ }^{9}$ Kode baris (barcode) adalah sebuah simbol yang melambangkan identitas suatu barang. Barcode merupakan instrumen yang bekerja berdasarkan asas kerja digital dan pemindai kode baris (barcode scanner) adalah alat yang digunakan untuk membaca kode-kode berbentuk garis-garis vertikal kode baris yang terdapat pada kebanyakan produk-produk consumer good.

10. Asep Id Hadiana, pemanfaatan teknologi qr code untuk verifikasi aktanotaris/ppat, Jurnal, aristoteles vol. 14 no. 1, april 2016 : hal. 38-39.

${ }^{11}$ Yuana, A. (2010). Rosihan, 67 Trik Dan Ide Brilian Master Php. Lokomedia: Yogyakarta. hlm. 198

${ }^{12}$ Meimaharani, R., \& Fithri, D. L. (2014). E-Commerce Goody Bag Spunbond Menggunakan QR Code Berbasis Web Responsif. Simetris: Jurnal Teknik Mesin, Elektro dan Ilmu Komputer, 5(2), 127-135. Hlm, 128

13. Barcode, http://www.adams1.com/stack.html, diakses pada 10 Februari 2019

${ }^{14}$ Widayati, Y. T. (2017). Aplikasi Teknologi Qr (Quick Response) Code Implementasi Yang Universal. Komputaki, 1(1). Hlm.87

${ }^{15}$ Hadiana, A. I. (2016). Pemanfaatan Teknologi QR Code Untuk Verifikasi Akta Notaris (PPAT). MIND Journal, l(1), 41.
} 
Organizing land registration is an effort to provide legal protection and legal certainty on various rights granted in accordance with applicable regulations so that it can be used as a proof of ownership over land. ${ }^{16}$ Output in the form of a deed of land based on specialiteite and openbaarheid principles is one of the objectives of Law No. 5 of 1960 concerning Basic Agrarian Regulations (UUPA 5 of 1960) as stated in Article 19 paragraph (1) that various efforts have been made to provide legal certainty and legal protection to deed holders. Basically, the governments have gradually carried out their task of organizing land registration done by the Head of Land Office who has the authority to register land assisted by PPAT and other officials to carry out various activities regulated in Article 6 of PP No. 24 of 1997 and other related legislations. PPAT has the authority to make certain deed ${ }^{17}$ namely the deed of transferring rights over land, including ownership rights to flats through exchange, grants, sale and purchase, and other legal acts of transferring rights, except the transfer of rights through an auction which can only be registered. ${ }^{18}$ Hence, PPAT is called as a Public Official because it is appointed by the authorized official ${ }^{19}$ that is assigned to serve community in certain fields or activities and is only appointed and dismissed by the Minister, ${ }^{20}$ including assigning PPAT temporarily ${ }^{21}$ into remote areas.

The theory of state administrative law declares that authority is the right or power possessed by an official or legal entity based the applicable regulations. Hence, authority can also be defined as a competency to take legal actions that can only be carried out in accordance with the code of conduct set in various formal regulations. Thus, authority is a form of formal power owned only by officials or institutions. Authority has an important position in constitutional law and state administrative law. Some experts even believe that authority is the core concept in constitutional law and state administrative law. ${ }^{22,23}$ In the same vein, Al-Kajangi declares that authority can also refer to private law and public law. ${ }^{24}$ On the contrary, other experts dichotomize between authority and power by stating that power is related to the right to do or not do, while authority implies the existence of rights and obligations. ${ }^{25}$ In organizing land registration in order to provide legal certainty over land, there are two parties whose interests need to be protected, namely: ${ }^{26}$

a. The interests of the holder of land rights so that he can prove that he is entitled to the land. By registering land, a certificate of ownership will be issued.

b. The interests of other parties, namely the interests of prospective buyers or creditors, so that they can easily obtain complete and trusted information.

\section{A. Before the enactment of Regulation of the Head of BPN RI No. 8 of 2012}

The blank is a form that is not yet filled in, while the deed is a proof containing a statement or acknowledgment about legal events made based on applicable regulations and witnessed by authorized officials. ${ }^{27}$ In this study, blank of land deed is a proof containing statement about a

\footnotetext{
${ }^{16}$ Santoso, 2010. Pendaftaran dan Peralihan Hak atas Tanah, Kencana Predana Media Group, Jakarta,16-17

17 Lidya Christina W.Tanggung Jawab Notaris/PPAT terhadap Aktayang Dibatalkan oleh Pengadilan, Jurnal, Lex Renaissance, No.1 Vol.2. Januari 2017, 61

${ }^{18}$ Lihat Pasal 37 ayat (1) PP 24 Tahun 1997 tentang Pendaftaran Tanah

${ }^{19}$ al Kajangi, M. D. M., Latief, A., \& Mustamin, H. (2004). Mandat, delegasi, attribusi, dan implementasinya di Indonesia . UII Press, 138-139

${ }^{20}$ Pasal 7 ayat (1) PP 24/1997

${ }^{21}$ Pasal 7 ayat (2) PP 24/1997

${ }^{22}$.Ridwan HR. Hukum Administrasi Negara. PT Raja Grafindo Persada. Jakarta 2013, 71

${ }^{23}$ Nurmayani ,Hukum Administrasi Daerah. Universitas Lampung Bandarlampung. 2009, 26.

${ }^{24}$ Al Kajangi, Op.,Cit, 1

${ }^{25}$ Hakim, L. (2011). Kewenangan Organ Negara Dalam Penyelenggaraan Pemerintahan. Jurnal Konstitusi, 4(1).

${ }^{26}$ Hendy Sarmyendra, Kekuatan Berlakunya Belangko Akta Tanah oleh Notaris/Pejabat Pembuat Akta Tanah dalam Pengalihan Hak Atas Tanah di Kabupaten Malinau Kalimantan Utara, Jurnal Baraja Niti, 3(4),3.

${ }^{27}$ Fakhriah, E. L. (2015). Perkembangan alat bukti dalam penyelesaian perkara perdata di pengadilan menuju pembaruan hukum acara perdata. Jurnal Hukum Acara Perdata ADHAPER, 1(2), 135-153, 140
} 
registration of land rights. ${ }^{28}$ There are several references related to the form of deed and authorized public officials in Indonesia, as stated in Book IV Article 1868 of the Civil Code and Government Regulation No. 37 of 1998 concerning the Position of Land Deed Officials in which these two legal bases describe the authority of PPAT as a public official. The word "make" 29 in this provision must be interpreted as creating deed in accordance with the form determined by Law as referred to in Article 1868 of the Civil Code. However, the word "make" in this study can be interpreted as realizing a valid deed through the information input process that is written in the blank of deed so that the final form of the blank can be declared as an authentic deed as it has passed the validation process of the authorized official.

There will be a contradiction when the authority is associated with Article 38 paragraph (2) of PP No. 24 of 1997 and Article 96 Paragraph (2) stating that the making of deed of land as referred to in Article 95 paragraph (1) and (2) of Regulation of the Minister of Agrarian Affairs/Head of the National Land Agency (BPN) No. 3 of 1997 must use the forms as referred to in Paragraph (1) in which Article 95 Paragraphs (1) and (2) state that the making of deed of land shall use the provided form/blank. Meanwhile, in terns of PPAT position, it has been regulated in Government Regulation No. 37 of 1998 in which the initial formation of regulations related to PPAT are originated from Article 7 Paragraph (3) of Government Regulation No. 24 of 1997 which is based on UUPA stating that the position of PPAT is regulated in a Government Regulation.

The blank of deed used by PPAT in land registration process contains a Serial Number at the top of the deed. The number is a code provided by the National Land Agency and there is no serial number that is the same so that it can be easily tracked when there is a problem. The deed is in the form of a book completed with a cover and there is a deed of land contained therein that is made in 4 copies. The color of the cover will be different for the deed of transfer rights and the deed of mortgage. The cover of the Deed of Sale and Purchase, the Deed of Grant, and the Deed of Joint Right Distribution are light green, while the cover of the Deed of Power of Attorney Granting Mortgage Rights and the Deed of Granting Mortgage Rights are pink. On the cover, there will be the serial number of the deed and the type of the deed. The contents of the deed have been determined by the National Land Agency in the blank provided and should be filled as complete as possible. PPAT needs to fill in the blank and if there is mistake, the blank must be revised and signed by ${ }^{30}$ PPAT and witnesses.

Before the enactment of Regulation of the Head of BPN RI No. 8 of 2012 concerning Amendment to Regulation of the Minister of Agrarian Affairs/Head of the National Land Agency (BPN) No. 3 of 1997, the serial number on the blank of land deed is prepared by BPN so that when there is a problem/dispute over land rights contained in the deed, BPN can immediately find out and trace the source or cause of the problem because the serial number on the blank of land deed contains data on the type of the blank, the name and area of PPAT using the blank, and the Land Office in the region. Yet, as the making of a deed of land is submitted to PPAT, the serial number cannot be used anymore. The concept of an authentic deed guarantees the power of proof and fulfills formal and material requirements, namely: ${ }^{31}$ a) The power of physical proof or acta publica probant sese ipsa where the power of this proof is the power orginating from the words contained in the deed so that it is considered an authentic deed until it can be proven otherwise. b) The power of formal proof means

\footnotetext{
${ }^{28}$ Darusman, Y. M. (2017). Kedudukan notaris sebagai pejabat pembuat akta otentik dan sebagai pejabat pembuat akta tanah. ADIL: Jurnal Hukum, 7(1), 36-56, 50

${ }^{29}$ Kemendikbud, Badan Pengembangan dan Pembinaan Bahasa, https://kbbi.kemdikbud.go.id/entri/membuat, Accessed 20 Januari 2019.

${ }^{30}$ Kurniawan, R. (2014). Implikasi Hukum Perubahan Pengaturan Tentang Blangko Akta Ppat Dalam Rangka Pendaftaran Tanah. Jurnal Hima Han, 1(2), 9

${ }^{31}$ Prahardika, R. B., \& Kawuryan, E. S. (2018) Tanggung Gugat Notaris Atas Kelalaian Dalam Membuat Akta Perjanjian Kredit Bank. Jurnal Transparansi Hukum, 1(1) , 47
} 
that an authentic deed can be proven from what is stated and included in the deed which is the description of the wishes of the parties on the authentic deed that guarantees the truth of the date, signature, and where the deed was made. c) The power of material proof is that legally, an authentic deed provides a form of certainty about the event in which officials or parties declare and do what is contained in the deed. ${ }^{32}$

\section{B. After the enactment of Regulation of the Head of BPN RI No. 8 of $2012^{33}$}

Since the enactment of Regulation of the Head of the National Land Agency No. 8 of 2012, all PPAT in regency/city no longer uses the blank of deed issued by BPN so that all blanks of deed are requested to be returned to the Land Official because PPAT starts using the new deed format in accordance with the Regulation of the Head of the National Land Agency No. 8 of 2012. However, on January 29, 2015, a regulation to reuse PPAT deed in accordance with Regulation of the Minister of Agrarian Affairs/Head of BPN No. 3 of 1997 was issued. The regulation which is stated in the Circular Letter of the Main Secretary or abbreviated SESTAMA No. 465/5.31-100///2015 on January 29, 2015 requires the re-use of the remaining blank of deed so that it needs to be redistributed to PPAT in regency/city and re-used in making deed of land. However, this regulation is not binding, meaning that it may be used and may not. Hence, it appears that the action is in accordance with Article II paragraph (1) letter a of the Regulation of Head of BPN RI No. 8 of 2012 concerning Amendment to the Regulation of the Minister of Agrarian Affairs/Head of BPN No. 31997.

Basically, there are positive and negative impacts of the enactment of this regulation. The positive impact of delegating authority of the making of a deed to PPAT is that land registration services become faster and more efficient and of course it returns the function of Land Deed Officials, ${ }^{34}$ namely the authority to make and print their own deed. Yet, there is also a negative impact that can occur in the future, namely the opportunity to make counterfeit blank of deed because it is easily made, not only by PPAT, but by all those who want to make it because there are examples in the appendix of the regulation as well as the procedures for filling it. On the other hand, sufficient technology is needed to make blank of deed in accordance with the applicable regulations, but not all regions in Indonesia have the same technology so that it is feared that there is a lack of technology or knowledge in remote areas that can have an impact on the delay in land registration process. ${ }^{35}$

\section{The Application of Barcode as a Substitution to Deed Registration Number in Providing Legal Certainty to Deed Made by PPAT}

The provision to no longer use registration number in a deed of land after the enactment of Regulation of the Head of BPN RI No. 8 of 2012, it is considered necessary to establish a security system to avoid duplicating efforts in order to maintain the validity of the deeds issued so that the party who has the original deed will not be harmed. Besides, efforts to increase the selling price of the deeds issued by the Central BPN can be avoided.

The application of barcode in each deed made by PPAT will maintain the authenticity of the Deed because the original data will appear when scanning the barcode so that the data verification officer can compare the data appeared with the data stored in the data base. Hence, if there is different data, the electronic system will automatically state that the deed is invalid and the data verification officer will provide an explanation related to the validity of the deed. The effort to

\footnotetext{
${ }^{32}$ Atika M. Amarie. Dkk. Analisis hukum terhadap otentisitas akta ppat (Legal Analysis of Authenticity Deed The Land Deed Official Makers).Artikel, Accessed 2018.

${ }^{33}$ Lihat Akta-Akta setelah diberlakukannya Peraturan Kepala Badan Pertanahan Nasional RI nomor 8 tahun 2012 tentang Perubahan Peraturan Menteri Negara Agraria/ Kepala Badan Pertanahan Nasional nomor 3 tahun 1997 tentang Peraturan Pelaksanaan Peraturan Pemerintah nomor 24 tahun 1997 tentang Pendaftaran Tanah

${ }^{34}$ Ali Achmad Chomzah, Hukum Agraria (Pertanahan) Indonesia Jilid 2, (Jakarta: Prestasi Pustakaraya, 2004), 66.

${ }^{35}$ Kurniawan, R. (2014). Implikasi Hukum Perubahan Pengaturan Tentang Blangko Akta Ppat dalam Rangka Pendaftaran Tanah. Jurnal HIMA HAN, 1(2), 9
} 
replace the registration number provided by PPAT with a barcode is expected to minimize counterfeit of a deed of land and the supervision can be easier and more transparent.

Interviews conducted to the Employees of the Office of National Land Agency and PPAT showed that to provide legal certainty and legal force against the Deed of land, the National Land Agency and PPAT accept the use of barcodes as a substitution to deed registration number made by PPAT. Yet, the application of barcode must be supported by adequate technological facilities so that its application can run as expected in order to provide legal certainty ${ }^{36}$ and legal force against the deed of land that has a barcode instead of registration number. The amendment of the regulation shows its efficiency through the acceleration of the procurement of deed made by PPAT. The needs of the community are accommodated with the development of regulations which provide a new hope which is more ideal. The role of PPAT to provide a legal certainty that seeks to achieve a form of legal justice often faces various challenges as legal certainty is often considered contradicting with legal justice. Yet, with the existence of legal certainty, it shows that legal justice of the community through legal certainty of using barcode began to be realized with the acceleration in making a deed of land needed by the community. Thus, in its practice, this legal certainty does not seem to ignore the principles of legal justice and vice versa.

If there is a conflict between legal certainty and legal justice, then legal justice should be prioritized because legal justice generally comes from the conscience, while legal certainty comes from a concrete condition. In this era of technology, justice has begun to enter the deed of land made by PPAT. Referring to the theory of legal certainty, right over land is determined by the functioning of 3 (three) things, namely:

a. Legal substance - consisting of objectives that contain norms/rules of the system and mechanism of land registration;

b. Legal structure - consisting of apparatus providing land services and institutions guaranteeing legal certainty as well as related government institutions;

c. Legal culture - consisting of community legal awareness and social reality.

The analysis shows that the application of barcodes on deed of land made by PPAT not only provides security and minimizes the occurrence of counterfeit of the deed, but also guarantees the validity of the deed as well as provides legal certainty. Although facilities and infrastructure as well as public legal awareness can be the obstacles, but the application of barcode to deed of land made by PPAT has provided legal justice and legal certainty. PPAT spread throughout the Unitary State of the Republic of Indonesia is PPAT which has a high capability in terms of education and has the ability to quickly find information. PPAT officials are now considered capable of facing various challenges as they have a high initiative and a strong prediction, especially related to deed of land ${ }^{37}$ because they have been trained to be able to solve problems when they are undergoing education in modern society which is full of risks and challenges.

\section{CONCLUSION}

Serial Number of Deed is a code contained on each blank of deed issued by BPN before the enactment of Regulation of the Head of BPN RI No. 8 of 2012. The number is a code issued by BPN and there is no same serial number so that it has the power of proof as the government is responsible for the registration number issued. After the enactment of Regulation of the Head of BPN RI No. 8 of 2012, the serial number contained on each blank of deed issued by BPN was replaced with a barcode from the blank of deed made by PPAT. The replacement of serial number to a barcode increasingly

\footnotetext{
${ }^{36}$ Rahmat Ramadhani, (2017), Jaminan Kepastian Hukum yang Terkandung dalam Sertipikat Hak Atas Tanah, Jurnal De Lega Lata 2(1),143-144.

${ }^{37}$ Lihat teori masyarakat resiko dan teknologi, Amajida, F. D. (2016). Kreativitas Digital Dalam Masyarakat Risiko Perkotaan: Studi Tentang Ojek Online “Go-Jek” Di Jakarta. Informasi, 46(1), 115-128, 117
} 
makes it easy for the community to get legal certainty. Basically, the Deed of Land with serial number issued by the National Land Agency has a strong power of proof, but the replacement of serial number to a barcode aims to avoid the emergence of double certificates or deeds of land that can cause legal uncertainty.

The application of barcode as a substitution to deed registration number as regulated in Regulation of the Head of BPN RI No. 8 of 2012 concerning Amendment to Regulation of the Minister of Agrarian Affairs/Head of the National Land Agency No. 3 of 1997 aims to maintain the validity of the deed of land made by PPAT. The QR Code technology (a three-dimensional barcode) in a special application will maintain the authenticity of the Deed of land because when scanning QR Code, the data will appear in the data verification officer who will then compare the data with the data base. Thus, it can guarantee legal certainty and legal protection on the deed holder which is faster than the previous method.

\section{SUGGESTION}

The government may not only rely on the concept in achieving the goal of providing legal certainty to right holders because there is a confusion on the rights of the land office to issue certificate numbers and other officials' rights governed by the law. In contrast, the government must gradually carry out its duties assisted by other officials to find the best pattern so that the problems concerning the replacement of registration number to barcode can be resolved as soon as possible and it can be implemented throughout the region.

The government must provide legal certainty in a variety of ways as a result of the application of technology to deed of land because the authenticity of the deed is often questioned due to the application of technology. The validation process in an effort to realize transparency that requires internet networks and electronic system devices sometimes becomes a barrier for those who are not part of the information society.

\section{REFERENCES}

Ali Achmad Chomzah, 2004. Hukum Agraria (Pertanahan) Indonesia Jilid 2, (Jakarta: Prestasi Pustakaraya.

Al Kajangi, M. D. M., Latief, A., \& Mustamin, H. (2004). Mandat, delegasi, attribusi, dan implementasinya di Indonesia. UII Press.

Boedi Harsono, (1978), Beberapa Analisis Tentang Hukum Agraria II, Esa Studi Klub, Jakarta.

Darusman, Y. M. (2017). Kedudukan notaris sebagai pejabat pembuat akta otentik dan sebagai pejabat pembuat akta tanah. ADIL: Jurnal Hukum, 7(1), 36-56.

Fakhriah, E. L. (2015). Perkembangan alat bukti dalam penyelesaian perkara perdata di pengadilan menuju pembaruan hukum acara perdata. Jurnal Hukum Acara Perdata ADHAPER, 1(2), 135153.

Gatra, D., Pasamai, S., Kadir, H., Buana, A. P., \& Aswari, A. (2018). Stagnancy of Land Use Arrangement Former Cultivation Rights. Substantive Justice International Journal of Law, 1(1), 1-8.

Hadiana, A. I. (2016). Pemanfaatan Teknologi QR Code Untuk Verifikasi Akta Notaris (PPAT). MIND Journal, 1(1)

Hakim, L. (2011). Kewenangan Organ Negara Dalam Penyelenggaraan Pemerintahan. Jurnal Konstitusi, 4(1).

Hayati, N. (2016). Peralihan Hak dalam Jual Beli Hak Atas Tanah (suatu Tinjauan terhadap Perjanjian Jual Beli dalam Konsep Hukum Barat dan Hukum Adat dalam Kerangka Hukum Tanah Nasional). Lex Jurnalica, 13(3). 
Hendy Sarmyendra, (2014) Kekuatan Berlakunya Belangko Akta Tanah oleh Notaris/Pejabat Pembuat Akta Tanah dalam Pengalihan Hak Atas Tanah di Kabupaten Malinau Kalimantan Utara, Jurnal Baraja Niti, 3(4).

Hidayat, E. Y., Firdausillah, F., \& Hastuti, K. (2015). Sistem Legalisir Scan Ijasah Online Berbasis QR Code dan Watermarking. Techno. Com, 14(1), 13-24.

Kurniawan, R. (2014). Implikasi Hukum Perubahan Pengaturan Tentang Blangko Akta Ppat Dalam Rangka Pendaftaran Tanah. Jurnal Hima Han, 1(2).

Lidya Christina W.Tanggung Jawab Notaris/PPAT terhadap Akta yang Dibatalkan oleh Pengadilan, Jurnal Lex Renaissance, 1(2).

Maria S.W. Sumardjono, dalam (Hendy Srmyendra dkk), Kekuatan berlakunya Penggunaan Blangko Akta oleh Notaris/Pejabat Pembuat Akta Tanah dalam Pengalihan Hak Atas Tanah di Kabupaten Malinau Kalimantan Utara, Jurnal Baraja Niti, 3(4)

Meimaharani, R., \& Fithri, D. L. (2014). E-Commerce Goody Bag Spunbond Menggunakan QR Code Berbasis Web Responsif. Simetris: Jurnal Teknik Mesin, Elektro dan Ilmu Komputer, 5(2), 127-135.

Novista, S. (2018). Tanggung Jawab Notaris-Ppat Dalam Mengeluarkan Covernote (Master's thesis, Universitas Islam Indonesia).

Nurmayani ,Hukum Administrasi Daerah. Universitas Lampung Bandarlampung. 2009

Purwaningsih, E., Praptomo, S., \& Rahmi, I. G. A. K. (2015). Keharusan Penggunaan Blangko Akta Ppat Berdasarkan Perkaban Nomor 8 Tahun 2012 di Kabupaten Sukoharjo. Repertorium, 3.

Prahardika, R. B., \& Kawuryan, E. S. (2018) Tanggung Gugat Notaris Atas Kelalaian Dalam Membuat Akta Perjanjian Kredit Bank. Jurnal Transparansi Hukum, 1(1).

Rahmat, Diding. 2017. Pengantar Hukum Pidana. Kuningan: Uniku Press. Amajida, F. D. (2016). Kreativitas Digital Dalam Masyarakat Risiko Perkotaan: Studi Tentang Ojek Online "Go-Jek" Di Jakarta. Informasi, 46(1), 115-128.

Rahmat Ramadhani, (2017), Jaminan Kepastian Hukum yang Terkandung dalam Sertipikat Hak Atas Tanah, Jurnal De Lega Lata 2(1).

Ridwan HR. Hukum Administrasi Negara. PT Raja Grafindo Persada. Jakarta 2013.

Rokhim, A. (2017). Hubungan Kontraktual Antara Pemerintah Dan Kontraktor Swasta Dalam Kontrak Pertambangan Minyak Dan Gas Bumi. Rechtidee, 12(1), 27-46.

Silviana, A. (2012). Kajian Tentang Kesadaran Hukum Masyarakat dalam Melaksanakan Pendaftaran Tanah. Pandecta: Research Law Journal, 7(1).

Urip Santoso, (2010). Pendaftaran dan Peralihan Hak atas Tanah, Kencana Predana Media Group, Jakarta.

Widayati, Y. T. (2017). Aplikasi Teknologi Qr (Quick Response) Code Implementasi Yang Universal. Komputaki, 1(1).

Yuana, A. (2010). Rosihan, 67 Trik Dan Ide Brilian Master Php. Lokomedia: Yogyakarta.

\section{Internet Sources}

Barcode, http://www.adams1.com/stack.html, diakses pada 10 Februari 2019

Kemendikbud, Badan Pengembangan dan Pembinaan Bahasa, https://kbbi.kemdikbud.go.id/entri/membuat, diakses 20 Januari 2019.

Atika M. Amarie. Dkk. Analisis hukum terhadap otentisitas akta PPAT (Legal Analysis of Authenticity Deed The Land Deed Official Makers). http://scholar.googleusercontent.com/scholar?q=cache:LOz7GAwX164J:scholar.google.com/ \&hl=id\&as_sdt=0,5 Artikel, diakses 11 Desember 2018. 


\section{Legislations}

Undang-Undang Dasar Negara Republik Indonesia Tahun 1945

Kitab Undang-undang Hukum Perdata (BW)

Undang-Undang Nomor 2 Tahun 2014 tentang Jabatan Notaris

Peraturan Kepala Badan Nomor 3 Tahun 1997 tentang Ketentuan Pelaksanaan Peraturan Pemerintah Nomor 24 Tahun 1997 tentang Pendaftaran Tanah

Peraturan Pemerintah Nomor 24 Tahun 1997 tentang Pendaftaran Tanah

Peraturan Pemerintah Nomor 27 Tahun 1998 tentang Peraturan Jabatan Pejabat Pembuat Akta Tanah

Peraturan Kepala Badan Pertanahan Nasional RI nomor 8 tahun 2012 tentang Perubahan Peraturan Menteri Negara Agraria/ Kepala Badan Pertanahan Nasional nomor 3 tahun 1997 tentang Peraturan Pelaksanaan Peraturan Pemerintah nomor 24 tahun 1997 tentang Pendaftaran Tanah 